Plant and Soil 170: 241-250, 1995.

(c) 1995 Kluwer Academic Publishers. Printed in the Netherlands.

\title{
Competition for ammonium between plant roots and nitrifying and heterotrophic bacteria and the effects of protozoan grazing
}

\author{
F.J.M. Verhagen ${ }^{1}$, H.J. Laanbroek ${ }^{2}$ and J.W. Woldendorp ${ }^{1}$ \\ ${ }^{1}$ Department of Plant Microorganism Interactions, Centre for Terrestrial Ecology, Netherlands Institute of Ecology, \\ P.O. Box 40, 6666 ZG Heteren, The Netherlands and ${ }^{2}$ Department of Microbial Ecology Centre for Limnology, \\ Netherlands Institute of Ecology, Rijksstraatweg 6, 3631 AC Nieuwersluis, The Netherlands
}

Received 14 March 1994. Accepted in revised form 4 August 1994

Key words: competition for ammonium, model systems, nitrification, $\mathrm{N}$-immobilization, $\mathrm{N}$-uptake by plant roots, protozoan grazing

\begin{abstract}
The competition for limiting amounts of ammonium between the chemolithotrophic ammonium-oxidizing species Nitrosomonas europaea, the heterotrophic species Arthrobacter globiformis and roots of Plantago lanceolata (Ribwort plantain) was studied in a series of model systems of increasing complexity, i.e. energy-limited continuous cultures, non-water-saturated continuously percolated soil columns and pots with $\gamma$-sterilized soil planted with axenic $P$. lanceolata seedlings. The effects of bacterial grazing by the flagellate species Adriamonas peritocrescens on the competition for ammonium were also investigated in the three model systems.

It was found that $N$. europaea was a weaker competitor for ammonium than either $A$. globiformis or plant roots of $P$. lanceolata. It is assumed that the heterotrophic bacteria have a higher affinity for ammonium than the nitrifying bacteria, whereas growing plant roots have a greater capacity to exploit the soil for ammonium than the immobile nitrifying bacteria. It is not very likely that allelochemicals were involved in suppressing the nitrification process. Four reasons are given for this assumption.

Presence of the flagellates strongly stimulated the potential nitrification rate in all model systems. It is assumed that there is a more even distribution over the soil of either nitrifying bacteria or their substrate ammonium in the presence of flagellates. In addition to the distribution effect, there is a stimulation of the potential ammonium oxidation rate. The results are discussed in the light of the function of nitrate as nitrogen sink in the biogeochemical nitrogen cycle.
\end{abstract}

\section{Introduction}

In the rhizosphere, plant roots and nitrifying and heterotrophic bacteria compete for ammonium that becomes available in the $\mathrm{N}$-mineralizationimmobilization turnover process or from fertilizer. This competition has been studied previously by others, but their results were not conclusive (Jansson, 1958; Riha et al., 1986; Rosswall, 1982; Zak et al., 1990). Jansson (1958) considered plant roots as the weakest competitors for ammonium and placed their ability compared with other organisms in soil in the following order: heterotrophic microflora $>$ nitrifying bacteria $>$ higher plants. He based his findings on planted pot experiments, in which heterotrophic bacteria with an excess of added organic carbon completely immobilized the mineral nitrogen. An argument opposing Janssons view is that plant roots are known to interfere with the $\mathrm{N}$-mineralization-immobilization turnover in the soil by the exudation of carbon. Rosswall (1982) measured $\mathrm{K}_{\mathrm{m}}$-values of 14,20 to 271 and 571 to $1286 \mu M$ for ammonium uptake by heterotrophic bacteria, roots and nitrifying bacteria, respectively. He concluded that the nitrifying bacteria were the weakest competitors for ammonium. Also in other studies, heterotrophic bacteria were found to be better competitors for the available ammonium than the nitrifying bacteria (Riha et al., 1986). In line with the 
results of Rosswall (1982) and Riha et al. (1986) are the observations of many authors that in unfertilized soils under a permanent cover of plants (e.g. grasslands and forests), the soil generally does not contain nitrate, numbers of nitrifying bacteria are low and plants do not contain nitrate or the inducible enzyme nitrate reductase (e.g. Moore and Waid, 1971; Purchase, 1974; Rice, 1982; Richardson, 1938; Theron, 1951, 1963; Woldendorp, 1963). However, it can be questioned whether the $\mathrm{K}_{m}$-values measured in homogeneously mixed culture solutions by Rosswall, apply to the soil where diffusion and mass flow (in the case of roots) are the operating forces. Differences in critical concentrations, below which no substrate can be taken up, are possibly more important.

The exudation of toxic compounds by plants was proposed as an alternative theory to explain the suppression of the nitrification process in the vicinity of roots (Basaraba, 1964; Moore and Waid, 1971; Munro, 1966; Rice and Pancholy, 1972; Theron, 1951). These so-called allelochemicals like (poly-)phenols and terpenes would be produced particularly by plant species from climax vegetations. It has been shown in laboratory studies that these compounds indeed may exert a toxic effect on the nitrification process. However, under field conditions, the accumulation of allelopathic compounds to levels toxic to nitrifying organisms has not been conclusively demonstrated. Moreover, ammonium oxidation by chemolithotrophic bacteria was not significantly retarded by the addition of phenols in concentrations that exceeded their concentration in soil (McCarty et al., 1991).

To obtain more insight in the competition for ammonium between plant roots and heterotrophic and nitrifying bacteria, a series of model experiments of increasing complexity was carried out involving representative species of each functional group. Protozoa were also included in the experiments, as these organisms have a stimulating effect on the nitrification process, e.g. by increased mineralization of organic nitrogen (Clarholm, 1985; Elliot et al., 1979; Kuikman and van Veen, 1989) or by excretion of growth factors (Griffiths, 1989). Of the species used, Nitrosomonas europaea and Nitrobacter winogradskyi are commonly observed nitrifying bacteria in the rhizosphere of Plantago lanceolata, whereas the heterotrophic species Arthrobacter globiformis and the novel flagellate species Adriamonas peritocrescens (Verhagen et al., 1994b) were isolated from the root zone of this plant species (Verhagen and Laanbroek, 1992). The experiments were carried out in continu- ous cultures, non-water-saturated soil columns and in pots with plants.

\section{Materials and methods}

\section{Continuous culture experiments}

Actively nitrifying cells of $N$. europaea were grown chemolithotrophically in chemostats in combination with $N$. winogradskyi at two dilution rates $(0.004$ and $0.01 \mathrm{~h}^{-l}$ ) with controlled $\mathrm{pH}$ and oxygen levels (for experimental details, see Verhagen and Laanbroek, 1991). N. winogradskyi was added to remove nitrite produced by $N$. europaea, by oxidizing it to nitrate. The chemostat was started batchwise with 2 $\mathrm{m} M$ ammonium in the inlet medium. Then the medium pumps were started and a steady state was awaited. The composition of the medium was (per liter): $\left(\mathrm{NH}_{4}\right)_{2} \mathrm{SO}_{4}, 0.132 \mathrm{~g} ; \mathrm{K}_{2} \mathrm{HPO}_{4}, 0.104 \mathrm{~g} ; \mathrm{KH}_{2} \mathrm{PO}_{4}, 19$ $\mathrm{mg} ; \mathrm{MgSO}_{4} .7 \mathrm{H}_{2} \mathrm{O}, 40 \mathrm{mg} ; \mathrm{CaCl}_{2}, 20 \mathrm{mg}, \mathrm{NaCl}, 0.5 \mathrm{~g}$; and trace element solution, $1 \mathrm{~mL}$. The composition of the trace element solution was (per liter): $\mathrm{FeCl}_{2} \cdot 4 \mathrm{H}_{2} \mathrm{O}$, $2.0 \mathrm{~g} ; \mathrm{Na}_{2}$-EDTA (Titriplex III), $4.3 \mathrm{~g} ; \mathrm{MnCl}_{2} \cdot 4 \mathrm{H}_{2} \mathrm{O}$, $0.1 \mathrm{~g} ; \mathrm{CoCl}_{2} \cdot 6 \mathrm{H}_{2} \mathrm{O}, 24 \mathrm{mg} ; \mathrm{NiCl}_{2} \cdot 6 \mathrm{H}_{2} \mathrm{O}, 24 \mathrm{mg}$; $\mathrm{CuCl}_{2} .2 \mathrm{H}_{2} \mathrm{O}, 17 \mathrm{mg} ; \mathrm{ZnCl}_{2}, 68 \mathrm{mg} ; \mathrm{Na}_{2} \mathrm{WO}_{4} .2 \mathrm{H}_{2} \mathrm{O}$, $33 \mathrm{mg} ; \mathrm{Na}_{2} \mathrm{MoO}_{4}, 24 \mathrm{mg}$; and $\mathrm{H}_{3} \mathrm{BO}_{3}, 62 \mathrm{mg}$. After a steady state situation was reached, a pure culture of $A$. globiformis was added and the inlet medium was supplemented with $1 \mathrm{~m} M$ glucose, whereas the ammonium concentration remained $2 \mathrm{~m} M$ during the experiment. After a new steady was reached, new medium with 2 $\mathrm{m} M$ glucose was introduced and subsequently the glucose concentration in the inlet medium was increased stepwise to $5 \mathrm{~m} M$ glucose. Steady state situations in the chemostats were detected chemically and microbiologically. Steady state situations in the chemostats were assumed in case of $\mathbf{A}$. constant concentrations of $\mathrm{NH}_{4}^{+}, \mathrm{NO}_{2}^{-}, \mathrm{NO}_{3}^{-}$and glucose over a time period of more than two weeks; and $\mathbf{B}$. constant numbers of nitrifying bacteria, heterotrophic bacteria and flagellates over a time period of more than two weeks. In the present chemostat experiments, steady state situations were reached after 7.5 and 3 weeks for the dilution rates of 0.004 and $0.01 h^{-1}$, respectively. The whole experiments in chemostats, taking 14 and 6 months each for $D=0.004$ and $0.01 \mathrm{~h}^{-1}$, respectively, were performed once. However, all determinations and bacterial counts on steady state situations were performed in triplicate. 
In a second experiment, the flagellate species monoxenically growing on $A$. globiformis, was added to the cultures after a steady state situation with 1 $\mathrm{m} M$ glucose was reached (Verhagen and Laanbroek, 1992). Glucose concentrations were again increased stepwise. At every steady state, samples were taken to determine ammonium, nitrite, nitrate, glucose, total and dissolved organic carbon concentrations and $\mathrm{pH}$. The numbers of nitrifying and heterotrophic bacteria were determined by Fluorescent Antibody (FA) counts and numbers of flagellates by Most Probable Number (MPN) and direct counts using a counting chamber. Medium reservoirs were sampled for determination of ammonium, glucose and $\mathrm{pH}$. Enumerations of heterotrophic bacteria by Plate Counting on a rich agar medium were also used as tests for purity of the mixed cultures. For experimental details, see Verhagen and Laanbroek (1991, 1992).

\section{Fluorescent antibody enumerations}

Nitrifying and heterotrophic bacteria were stained on black polycarbonate membrane filters (pore size $0.2 \mu \mathrm{m}$ ) (Nuclepore Corp., Pleasanton, California, U.S.A.), using antiserum prepared from blood from an immunized New Zealand rabbit and goat-anti-rabbit antiserum, which was labeled with the green fluorescent label FITC (fluorescein isothiocyanate) (Sigma Chemie, Axel, The Netherlands).

\section{Most probable number enumerations}

For the enumerations of flagellates, A. globiformis was used as the food bacterium. Samples taken from the culture vessels were diluted fourfold in microtiter plates (tissue culture cluster, 24 wells)(Costar, Cambridge, UK) containing $0.75 \mathrm{~mL}$ of a dense pure culture of A. globiformis. Twelve replicates were made per dilution. After incubation for 12 days at $20^{\circ} \mathrm{C}$, wells were tested for flagellate growth using an inverted microscope. Numbers of flagellates were obtained from statistical tables that were generated by a computer program.

\section{Soil column experiments}

In a second series of experiments, nutrient media were added continuously to a series of $\gamma$-sterilized soil columns, which were inoculated with the same pure cultures as in the continuous culture experiments. Soil was collected in a grassland near Brummen, The Netherlands $(0-30 \mathrm{~cm})$. The sieved $(2 \mathrm{~mm})$, mixed soil contained $21 \%$ coarse sand, $70 \%$ fine sand, $4 \%$ silt, and $5 \%$ clay. The $\mathrm{pHs}$ of $\mathrm{H}_{2} \mathrm{O}$ - and $\mathrm{KCl}$-extracts were 7.8 and 7.4, respectively. The $\mathrm{CaCO}_{3}$ content was 4.2 $\%$.

The soil columns were percolated with medium containing (per liter): $\left(\mathrm{NH}_{4}\right)_{2} \mathrm{SO}_{4}, 0.33 \mathrm{~g} ; \mathrm{KH}_{2} \mathrm{PO}_{4}$, $0.1 \mathrm{~g} ; \mathrm{MgSO}_{4} .7 \mathrm{H}_{2} \mathrm{O}, 40 \mathrm{mg} ; \mathrm{CaCl}_{2}, 20 \mathrm{mg} ; \mathrm{NaCl}$, $0.5 \mathrm{~g}$; trace element solution, $1 \mathrm{~mL}$ (composition see above); and glucose. $\mathrm{H}_{2} \mathrm{O}, 0.40,0.79,1.19,1.59,1.98$, or $2.38 \mathrm{~g}$. The final $\mathrm{pH}$ after sterilization was 7.5 . The dilution rate was $0.007 \mathrm{~h}^{-1}$ based on liquid volumes of the soil. A water column of $1 \mathrm{~m}$ maintained a soil moisture content of $24 \%$, which was $60 \%$ of the water holding capacity of this soil.

Samples of the percolates of the soil columns were taken three times per week to determine ammonium, nitrite, nitrate, glucose and $\mathrm{pH}$. After 10-13 weeks of percolation, the soil columns were harvested. At harvesting, dissolved oxygen concentrations were measured in the uppermost $4 \mathrm{~cm}$ and at a depth of $7 \mathrm{~cm}$ of one soil column, which was percolated with medium containing $5 \mathrm{~m} M$ ammonium and $10 \mathrm{~m} M$ glucose. At harvesting, each column was divided into three parts: layer A, 0-3 cm; layer B, 3-6 cm; layer R, 6-15 $\mathrm{cm}$. In each layer, numbers of nitrifying bacteria were determined by FA counts (see above). In addition, the potential ammonium- and nitrite-oxidizing activities were determined. Numbers of heterotrophic bacteria were determined by FA counts (see above) and those of flagellates by MPN counts (see above). Soil mineral nitrogen concentrations and $\mathrm{pH}$ were determined in $1 \mathrm{M}$ $\mathrm{KCl}-(1: 5)$ and in water-extracts (1:2.5), respectively. Soil organic matter contents were also determined (see below). Samples of the medium reservoirs were taken to determine $\mathrm{pH}$ and concentrations of ammonium and glucose. For experimental details, see Verhagen et al. $(1992,1993)$. The whole soil column experiments, taking 10 months each, were conducted once. However, all determinations and bacterial counts were performed in triplicate.

\section{Potential nitrifying activity}

Potential nitrifying activities were determined in duplicate. Samples $(10.0 \mathrm{~g})$ of well-mixed soil were mixed with $50 \mathrm{mg}$ of $\mathrm{CaCO}_{3}$ and $25 \mathrm{~mL}$ medium containing (per liter): $\left(\mathrm{NH}_{4}\right)_{2} \mathrm{SO}_{4}, 0.33 \mathrm{~g} ; \mathrm{K}_{2} \mathrm{HPO}_{4}, 139 \mathrm{mg}$; and $\mathrm{KH}_{2} \mathrm{PO}_{4}, 27 \mathrm{mg}$. The $\mathrm{pH}$ of the medium was 7.5 . No inhibitors were applied. The mixtures were incubated at $25^{\circ} \mathrm{C}$ and stirred at $150 \mathrm{rpm}$. The formation of nitrite and nitrate was followed for 6 hours. Sam- 
ples $(1 \mathrm{~mL})$ were taken every hour to determine the nitrite and nitrate concentrations. After centrifugation of a sample at $15,000 \times \mathrm{g}$ in a Biofuge A table centrifuge for $5 \mathrm{~min}$., $0.50 \mathrm{~mL}$ of the clear supernatant was mixed with $0.50 \mathrm{~mL}$ of a $2 \mathrm{M} \mathrm{KCl}$ solution. Samples were stored at $4^{\circ} \mathrm{C}$ and analyzed within 1 day. Potential ammonium-oxidizing activities were calculated from the sum of the amounts of nitrite and nitrate formed. The rates of nitrite and nitrate formation were calculated by linear regression. Potential nitrite-oxidizing activities could be calculated from the formation of nitrate only when accumulation of nitrite appeared.

\section{Soil organic matter content}

The organic matter contents of the soil were determined by the analysis of weight losses after heating samples of $5.00 \mathrm{~g}$ of dry soil at $550^{\circ} \mathrm{C}$ for 4 hours. Determinations were done in duplicate.

\section{Pot experiments with plants}

The interactions between the various groups of organisms were studied in pots with $\gamma$-sterilized soil with or without axenic $P$. lanceolata plants that were fertilized or not. The soil used in this experiment was identical to the soil used in the soil column experiments.

To obtain sterile seedlings, 1 year-old seeds of $P$. lanceolata (hayfield type) were scoured with $96 \%$ $(\mathrm{v} / \mathrm{v})$ ethanol for 1 minute and thereupon they were treated with $1 \%(\mathrm{w} / \mathrm{v})$ sodium hypochlorite solution for 10 minutes. The seeds were thoroughly rinsed with sterile water and to check for bacterial infections, they were placed on an agar medium containing (per liter): "Lab-Lemco" broth (Oxoid Ltd., Basingstoke, England), $1.0 \mathrm{~g}$; yeast extract (Difco Laboratories, Detroit, U.S.A.), $2.0 \mathrm{~g}$; tryptose (Oxoid), $5.0 \mathrm{~g}$ and glucose. $\mathrm{H}_{2} \mathrm{O}, 1.0 \mathrm{~g}$. The final $\mathrm{pH}$ of the agar medium was 7.5. Seeds were examined and turned after 2 days and after another 2 days, they were transferred to a malt agar medium to check for fungal infections. The malt agar medium contained (per liter): malt extract (Oxoid), $8.0 \mathrm{~g}$ and mycological peptone (Oxoid), $3.0 \mathrm{~g}$. Seeds were examined and turned after 2 days and noninfected seeds were transferred after another 2 days to water agar medium in order to germinate. Test agar plates for bacterial and fungal infections were incubated for another 2 weeks at $20^{\circ} \mathrm{C}$ to confirm sterility.

Half the planted and unplanted pots both with and without flagellates were fertilized weekly. In the first week, fertilization was (mg per pot): $\left(\mathrm{NH}_{4}\right) \mathrm{H}_{2} \mathrm{PO}_{4}$,

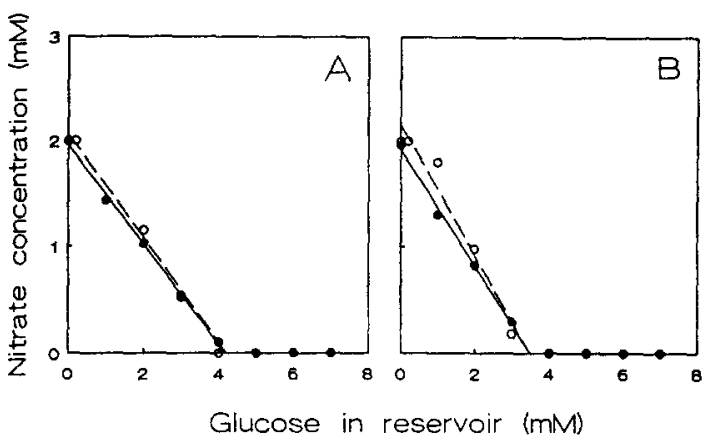

Fig. 1. Steady state concentrations of nitrate in continuous cultures containing $N$. europaea, $N$. winogradskyi and $A$. globiformis, in the presence (drawn lines) and absence (broken lines) of the flagellate Adriamonas peritocrescens, with increasing glucose concentrations in the inlet medium at dilution rates of 0.004 (A) and $0.01(B) h^{-1}$.

2.66; $\left(\mathrm{NH}_{4}\right)_{2} \mathrm{SO}_{4}, 5.35 ; \mathrm{KCl}, 5.18$ and $\mathrm{MgSO}_{4} .7 \mathrm{H}_{2} \mathrm{O}$, 2.85. Amounts of nutrients were increased weekly by a factor of 1.37 . In total $320 \mathrm{mg} \mathrm{N}$ was given to each fertilized pot. A trace element solution (composition see above) was added to the nutrient solution every 2 weeks.

Pots with or without plants were harvested after 14 weeks. When a plant was harvested, the soil was removed from the roots and fresh and dry weights of roots and shoots were determined. In addition, total and mineral nitrogen concentrations in the dried ground plant material were measured. Soil from each pot was mixed well. Numbers of ammonium- and nitriteoxidizing bacteria and of flagellates were determined by FA and MPN counts, respectively. In addition, the potential ammonium- and nitrite-oxidizing activities were determined by incubation of soil suspensions under optimal conditions (see above). Numbers of heterotrophic bacteria were established using specific antibody fluorescence microscopy. Soil mineral nitrogen concentrations and $\mathrm{pH}$ were determined in 1 $M \mathrm{KCl}$-extracts (1:5) and in water-suspensions (1:2.5), respectively. Soil organic matter contents were determined by analysis of weight losses after heating dry soil at $550^{\circ} \mathrm{C}$ for 4 hours. For experimental details, see Verhagen et al. (1994a).

\section{Results}

\section{Continuous culture experiments}

The nitrate concentration decreased at increasing glucose concentrations and above a certain glucose con- 
Table 1. Specific potential activities of $N$. europaea cells grown in the presence of $N$. winogradskyi and $A$. globiformis, and in the absence $(-F)$ and presence $(+F)$ of the flagellate species $A$. peritocrescens, in the three layers of the soil columns after percolation for 13 weeks with media containing $5 \mathrm{~m} M$ ammonium and different concentrations of glucose at a dilution rate of 0.007 per hour based on liquid volumes. Cells were enumerated with a Fluorescent Antibody (FA) technique and activities were determined by potential ammonium-oxidizing activity measurements

\begin{tabular}{|c|c|c|c|c|c|c|}
\hline \multirow{3}{*}{$\begin{array}{l}\text { Glucose in reservoir } \\
(\mathrm{m} M)\end{array}$} & \multicolumn{6}{|c|}{ Specific potential activity ( $\mathrm{pmol} \mathrm{NH}{ }_{4}^{+}$cell-1 $\mathrm{h}^{-1}$ ) } \\
\hline & \multicolumn{2}{|c|}{ layer $\mathrm{A}$} & \multicolumn{2}{|c|}{ layer B } & \multicolumn{2}{|c|}{ layer $\mathrm{R}$} \\
\hline & $-F$ & $+\mathrm{F}$ & $-\mathrm{F}$ & $+\mathrm{F}$ & $-\mathrm{F}$ & $+F$ \\
\hline 0 & 0.30 & 2.31 & 0.63 & 3.83 & 1.39 & 4.47 \\
\hline 2 & 0.43 & 2.11 & 0.73 & 4.86 & 1.43 & 3.88 \\
\hline 4 & 0.28 & 1.93 & 0.51 & 3.97 & 1.37 & 4.55 \\
\hline 6 & 0.18 & 1.27 & 0.37 & 3.38 & 1.32 & 2.80 \\
\hline 8 & 0.06 & 1.65 & 0.25 & 3.61 & 1.44 & 3.10 \\
\hline 10 & 0.01 & 1.70 & 0.28 & 5.49 & 1.02 & 1.89 \\
\hline 12 & 0 & 2.76 & 0.60 & 8.87 & 1.24 & 5.47 \\
\hline
\end{tabular}

Layer A: $0-3 \mathrm{~cm}$ from top; layer B: $3-6 \mathrm{~cm}$ from top; layer $\mathrm{R}: 6-15 \mathrm{~cm}$ from top.

Table 2. Ammonium concentrations in the three layers of the soil columns containing $N$. europaea, $N$. winogradskyi and $A$. globiformis in the absence $(-\mathrm{F})$ and presence $(+\mathrm{F})$ of the flagellate $A$. peritocrescens, after percolation for 13 weeks with media containing $5 \mathrm{~m} M$ ammonium and different concentrations of glucose at a dilution rate of 0.007 per hour based on liquid volumes

\begin{tabular}{|c|c|c|c|c|c|c|}
\hline \multirow{3}{*}{$\begin{array}{l}\text { Glucose in reservoir } \\
(\mathrm{m} M)\end{array}$} & \multicolumn{6}{|c|}{$\left[\mathrm{NH}_{4}^{+}\right]\left(\mu \mathrm{g} \mathrm{N} \mathrm{g}^{-1}\right.$ dry soil $)$} \\
\hline & \multicolumn{2}{|c|}{ layer $\mathrm{A}$} & \multicolumn{2}{|c|}{ layer B } & \multicolumn{2}{|c|}{ layer $\mathrm{R}$} \\
\hline & $-F$ & $+\mathrm{F}$ & $-F$ & $+F$ & $-F$ & $+\mathrm{F}$ \\
\hline 0 & 171 & 146 & 46 & 89 & 26 & 56 \\
\hline 2 & 142 & 107 & 12 & 69 & 8 & 53 \\
\hline 4 & 194 & 110 & 6 & 73 & 12 & 59 \\
\hline 6 & 218 & 114 & 11 & 74 & 22 & 63 \\
\hline 8 & 219 & 106 & 70 & 76 & 29 & 59 \\
\hline 10 & 230 & 93 & 41 & 67 & 17 & 46 \\
\hline 12 & 228 & 75 & 4 & 52 & 5 & 36 \\
\hline
\end{tabular}

Layer A: $0-3 \mathrm{~cm}$ from top; layer B: $3-6 \mathrm{~cm}$ from top; layer $\mathrm{R}: 6-15 \mathrm{~cm}$ from top.

centration no nitrate was found (Fig. 1). It was concluded that below this critical glucose concentration the heterotrophic bacteria were carbon limited and $N$. europaea was limited by ammonium. Under these conditions both species, each limited by a different substrate, could coexist in a steady state situation (Laanbroek et al., 1979). However, with increas- ing glucose concentrations and concomitantly growing demands for ammonium by the heterotrophic bacteria, $N$. europaea lost the competition for ammonium as becomes apparent from the decreasing nitrate concentration. Above the critical glucose concentration, ammonium also limited the growth of the Arthrobacter species and no substrate was available for $N$. 
Table 3. Mineral nitrogen concentrations in pots with sterilized soil containing $N$. europaea and $N$. winogradski, after incubation for 15 weeks at $20 / 15^{\circ} \mathrm{C}$ for $14 / 10 \mathrm{~h}$ per day. The soil moisture content was $24 \%$ (60\% WHC) and the light intensity $236 \mu \mathrm{E} \mathrm{s}^{-1} \mathrm{~m}^{-2}$

\begin{tabular}{lllll}
\hline Treatment & $\begin{array}{l}\mathrm{NH}_{4}^{+} \\
\left(\mu \mathrm{g} \mathrm{N} \mathrm{g}^{-1}\right)\end{array}$ & $\begin{array}{l}\mathrm{NO}_{2}^{-} \\
\left(\mu \mathrm{g} \mathrm{g} \mathrm{g}^{-1}\right)\end{array}$ & $\begin{array}{l}\mathrm{NO}_{3}^{-} \\
\left(\mu \mathrm{g} \mathrm{N} \mathrm{g}^{-1}\right)\end{array}$ & $\begin{array}{l}\text { Total mineral N } \\
\left(\mu \mathrm{g} \mathrm{N} \mathrm{g}^{-1}\right)\end{array}$ \\
\hline- & $75.6 \mathrm{c} *$ & $0.3 \mathrm{a}$ & $56.3 \mathrm{~b}$ & $132.2 \mathrm{~b}$ \\
$\mathrm{G}$ & $48.6 \mathrm{~b}$ & $0.7 \mathrm{a}$ & $75.9 \mathrm{c}$ & $125.2 \mathrm{~b}$ \\
$\mathrm{~F}$ & $366.5 \mathrm{e}$ & $0.3 \mathrm{a}$ & $85.4 \mathrm{~d}$ & $452.2 \mathrm{c}$ \\
$\mathrm{GF}$ & $311.5 \mathrm{~d}$ & $0.6 \mathrm{a}$ & $142.8 \mathrm{e}$ & $454.9 \mathrm{c}$ \\
& & & & \\
$\mathrm{P}$ & $0.8 \mathrm{a}$ & 0 & $0.3 \mathrm{a}$ & $1.1 \mathrm{a}$ \\
PG & $0.7 \mathrm{a}$ & 0 & $0.2 \mathrm{a}$ & $0.9 \mathrm{a}$ \\
$\mathrm{PF}$ & $1.4 \mathrm{a}$ & 0 & $0.3 \mathrm{a}$ & $1.7 \mathrm{a}$ \\
$\mathrm{PGF}$ & $1.0 \mathrm{a}$ & 0 & $0.3 \mathrm{a}$ & $1.3 \mathrm{a}$ \\
\hline
\end{tabular}

$\mathrm{G}=$ grazers (flagellates); $\mathrm{F}=$ fertilizer $\left(\mathrm{NH}_{4}^{+}\right) ; \mathrm{P}=$ plant $(P$. lanceolata).

Concentrations are expressed in $\mu \mathrm{g} \mathrm{N} \mathrm{g}^{-1}$ dry soil.

Values are means of 5 replicate experiments.

* Values within each column followed by a different letter are significantly

different $(p<0.05)$ according to Tukey's test.

Table 4. Numbers and potential ammonium-oxidizing activities of N. europaea added to pots with sterilized soil, in the presence of $N$. winogradskyi after incubation for 15 weeks at $20 / 15^{\circ} \mathrm{C}$ for $14 / 10 \mathrm{~h}$ per day. The soil moisture content was $24 \%$ (60\% WHC) and the light intensity $236 \mu \mathrm{E} \mathrm{s}^{-1} \mathrm{~m}^{-2}$

\begin{tabular}{lcc}
\hline Treatment & $\begin{array}{c}\text { Numbers of } N \text {. europaea } \\
\left(\times 10^{6} \mathrm{~g}^{-1} \text { dry soil }\right)\end{array}$ & $\begin{array}{c}\text { Activities of } N \text {. europaea } \\
\left(\mu \mathrm{mol} \mathrm{NH} \mathbf{H}^{+} \mathrm{h}^{-1} \mathrm{~g}^{-1} \text { dry soil }\right)\end{array}$ \\
\hline- & $88 \mathrm{~b} *$ & $132 \mathrm{~b}$ \\
G & $175 \mathrm{~b}$ & $189 \mathrm{c}$ \\
F & $249 \mathrm{~b}$ & $180 \mathrm{c}$ \\
GF & $334 \mathrm{~b}$ & $325 \mathrm{~d}$ \\
P & & \\
PG & $6.2 \mathrm{a}$ & $3.3 \mathrm{a}$ \\
PF & $1.0 \mathrm{a}$ & $0.8 \mathrm{a}$ \\
PGF & $0.9 \mathrm{a}$ & $0.4 \mathrm{a}$ \\
\hline
\end{tabular}

$\mathrm{G}=$ grazers (flagellates); $\mathrm{F}=$ fertilizer $\left(\mathrm{NH}_{4}^{+}\right) ; \mathrm{P}=$ plant $(P$. lanceolata $)$.

Numbers of $N$. europaea were determined by Fluorescent Antibody (FA) counts.

Values are means of 5 replicates.

* Values within each column followed by a different letter are significantly different

$(p<0.05)$ according to Tukey's test.

europaea. These conclusions could be confirmed by bacterial counts, i. e. Fluorescent Antibody counts of $N$. europaea (Fig. 2) and A. globiformis (Fig. 3). The critical glucose concentration was higher at the lower dilution rate of $0.004 \mathrm{~h}^{-1}$, which was assumed to be due to the fact that proportionally more glucose was used by the heterotrophs for maintenance at the lower dilution rate. There was no significant effect of grazing by the flagellate on nitrate concentrations and the critical glucose concentrations. Apparently, there was no increased mineralization of $A$. globiformis to ammonium by the grazing activities of the flagellates. Taking 


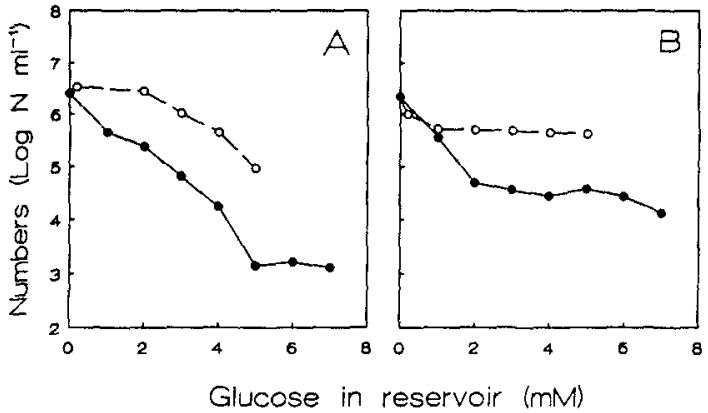

Fig. 2. Steady state numbers of $N$. europaea cells grown in continuous cultures in the presence (drawn lines) and absence (broken lines) of the flagellate Adriamonas peritocrescens, with increasing glucose concentrations in the inlet medium at dilution rates of 0.004 (A) and 0.01 (B) $\mathrm{h}^{-1}$. Cells were enumerated with a Fluorescent Antibody technique (see Materials and methods).

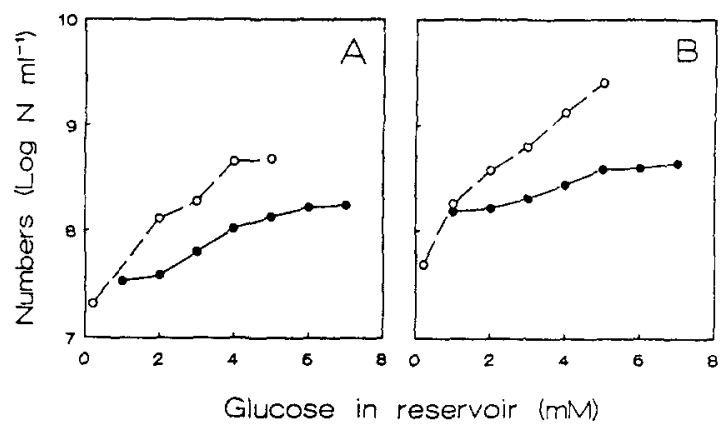

Fig. 3. Steady state numbers of $A$. globiformis cells grown in continuous cultures in the presence (drawn lines) and absence (broken lines) of the flagellate Adriamonas peritocrescens, with increasing glucose concentrations in the inlet medium at dilution rates of 0.004 (A) and 0.01 (B) $\mathrm{h}^{-1}$. Cells were enumerated with a Fluorescent Antibody technique (see Materials and methods).

into account that the numbers of $A$. globiformis were reduced by more than 50 per cent by the flagellates, this result could only be explained by assuming that a large part of the consumed bacteria were not completely mineralized to ammonium.

The protozoa reduced the FA numbers of $N$. europaea to about 5 per cent of those without grazing (Fig. 2). Nevertheless, the rate of nitrate production was not lowered (Fig. 1). This confirms the results of other authors (Belser and Mays, 1982; Berg and Rosswall, 1985) that usually the numbers of nitrifying bacteria and their activities are not correlated. It could be calculated that the growth rate of $N$. europaea had increased considerably in the presence of flagellates (Pirt, 1975), even to such a degree that the results can only be explained if some growth on the wall of the culture vessels is assumed to have taken place. The fact that $N$. europaea above the critical glucose concentration was not washed out completely also points to the occurrence of growth on the vessel walls.

In conclusion, it was found that in the continuous culture experiments $N$. europaea lost the competition for limiting amounts of ammonium from the common soil bacterium $A$. globiformis. The growth rate and the rate of ammonium oxidation per cell are stimulated by the flagellates by unknown mechanisms. Similar results were obtained by Griffiths (1989) in liquid cultures. He ascribed the stimulating effects of the protozoa to unknown growth factors.

\section{Non-water-saturated soil columns}

The percolated soil columns appeared to be a rather complex system as, theoretically, a steady state in the numbers of A. globiformis was reached only when all added glucose was used for maintenance of the heterotrophic population that has been built up. In a steady state situation such like this, A. globiformis does not need additional ammonium. The ammonium then becomes completely available to $N$. europaea. $N$. europaea theoretically will build up a population which finally uses all ammonium for maintenance. Then, all ammonium in the inlet medium will be converted quantitatively into nitrate. In the experiments described in this section, the intermediate states of competition between the populations were studied and final steady state situations were not reached.

In these intermediate states, the nitrate concentrations in the percolates decreased at increasing glucose concentrations in the influent and became zero at the highest glucose concentration of $12 \mathrm{mM}$. Apparently, also in the soil columns $N$. europaea was a weaker competitor for ammonium than A. globiformis, as could also be confirmed by the decreasing potential nitrifying activities with increasing glucose concentrations. In the ungrazed columns, the FA numbers of $N$. europaea were hardly lower at increasing glucose concentrations. However, in the three soil layers that were analyzed, the potential ammonium-oxidizing activities decreased sharply, particularly in the upper layer (Table 1). In contrast to the continuous cultures, in the grazed columns the numbers of $N$. europaea hardly decreased as glucose concentrations increased, but their potential ammonium-oxidizing activities were much higher than in the ungrazed columns (Table 1). In the ungrazed as well as in the grazed columns, accumulation of inorganic nitrogen was found. The accumulated nitrogen was in the form of ammonium. In the grazed columns, 
the accumulation of ammonium was lower and the ammonium was more evenly distributed over the three soil layers (Table 2).

Because the system was not ammonium-limited, the positive effect of the flagellate on the nitrification rate could not be ascribed to an increased Nmineralization. The results can be explained by assuming that there is a spatial separation between the ammonium-oxidizing cells and their substrate ammonium. The positive effect of the flagellate can be ascribed to a more even distribution over the soil of either the nitrifying bacteria or their substrate ammonium.

\section{Pot experiments with plants}

It appeared that in the unplanted pots the flagellates and fertilization with ammonium both stimulated the production of nitrate and there was a strong interaction between both factors (Table 3). Because in none of the treatments without plants the nitrifying bacteria were ammonium limited, it was concluded that also in this experiment the flagellates stimulated the nitrification process. This stimulation was reflected in the numbers of $N$. europaea cells and their potential ammoniumoxidizing activities (Table 4). There was no effect of the flagellates on the mineralization of organic nitrogen as the total amounts of mineral nitrogen in the unplanted pots did not increase. As a similar stimulating effect on the nitrification process was found by the addition of more ammonium to the non- ammonium limited systems, the results strongly suggest that the flagellates improve the contact between nitrifying bacteria and ammonium. However, the homogenizing effect of the protozoa can not fully explain their positive effect on the nitrification process, since a stimulation of the specific potential ammonium-oxidizing activity (expressed per cell) by the flagellates was also found in the homogeneously stirred continuous cultures (see above). Therefore, additional stimulating effects of growth substances also need to be considered, as has been suggested by Griffiths (1989).

In the planted soil, no mineral nitrogen was present (Table 3 ) and the numbers of $N$. europaea and their potential activities were severely reduced (Table 4). No effects of the flagellates on these parameters were found. It is concluded that $N$. europaea is the weaker competitor for limiting amounts of ammonium in the competition with plant roots.

\section{Discussion}

The results showed that $N$. europaea looses the competition for ammonium from the heterotrophic species A. globiformis as well as from roots of $P$. lanceolata. In the case of the competition between $N$. europaea and $A$. globiformis, inhibiting bacterial compounds suppressing the nitrifying bacteria were probably not involved. In separate experiments, it was shown that $N$. europaea is neither inhibited by glucose or by cellfree culture filtrates of stationary-phase $A$. globiformis cells. Apparently, the higher affinity for $\mathrm{NH}_{4}^{+}$of $A$. globiformis makes that this organism wins the competition for ammonium.

In the pot experiment, the actual mechanism by which plant roots suppressed the numbers and potential activities of the nitrifying bacteria (Table 4) could not be established. Due to the absence of mineral nitrogen in the pots with plants, it was concluded that the system was ammonium limited over the whole period. This is confirmed by the fact that the maximum relative growth rate of $P$. lanceolata is 1.85 per week (Freijsen and Otten, 1987; Kuiper and Bos, 1992), whereas an exponentially increasing ammonium addition rate of 1.37 per week was applied in the present pot experiment. One possible explanation is that the inhibition of the nitrification process is due to allelochemicals originating from the roots of $P$. lanceolata. Howev$\mathrm{er}$, it is not likely that allelochemicals were involved for the following four reasons. Reason 1 was concluded from the present experiments, whereas reasons 2,3 and 4 were described in literature. 1. No inhibition of ammonium oxidation was found in the least-diluted soil suspensions of the MPN-counts of nitrifying bacteria. 2. In axenic non-ammonium limited model systems of $P$. lanceolata with mixed cultures of $N$. europaea, two Nitrobacter species and a Pseudomonas species which enabled the examination of the spatial distribution around plant roots on a microscopic scale - a positive interaction of $N$. europaea with the plant roots was found (Both, 1990). This stimulation of $N$. europaea in the rhizosphere was probably due to interaction with the ammonifying Pseudomonas species, that was stimulated much more in the rhizosphere. 3. Newman and Miller (1977) extracted organic compounds from $P$. lanceolata that were toxic to germinating seeds of other plant species, but upon repeated addition of these extracts to the soil, this effect completely disappeared. Apparently, the appropriate micro-organisms that rapidly decomposed the toxic compound, had been enriched. 4. It has been reported that under field condi- 
tions a possible excess of ammonium is nitrified in the rhizosphere of $P$. lanceolata (Blacquière and Troelstra, 1991; Troelstra, 1992). Under uniform weather conditions, a close relationship was observed between the numbers of nitrifying bacteria in the rhizosphere and the inducible enzyme nitrate reductase in the shoots of P. lanceolata (Smit and Woldendorp, 1981). All of these observations do not point into the direction of allelochemicals being involved in the suppression of nitrification in the rhizosphere of $P$. lanceolata. In other situations and with other plant species, such a suppression has often been reported (Basaraba, 1964; Moore and Waid, 1971; Munro, 1966; Rice and Pancholy, 1972). However, these results are not convincing, as they are based on experiments in which plant extracts were added only once to the soil and not repeatedly as was done in the experiments of Newman and Miller (1977), whereas the accumulation of toxic compounds in the soil to inhibiting levels was not demonstrated. Moreover, conclusive experiments with plants have to be done with non-limiting amounts of ammonium in order to eliminate inhibition by mechanisms other than allelochemicals.

The higher competitive ability of plant roots for ammonium may be related to a greater capacity of exploiting the soil by the formation of new roots, particularly when grown in pots. The results of the percolated soil columns and the unplanted pots indicate that without the aid of organisms such as protozoa, the nitrifying bacteria are less capable of exploiting the ammonium in the soil efficiently.

In conclusion, the series of model experiments in continuous cultures, soil columns and pots with plants clearly showed that $N$. europaea is the weaker one in the competition for ammonium with A. globiformis and $P$. lanceolata. Consequently, nitrification generally only takes place when ammonium is present in non-limiting amounts. This result is in line with the function of nitrate as a sink for a surplus of nitrogen and with the concept that in biogeochemical cycles the most oxidized state of an element (in this case nitrate) only occurs if there is a lack of available energy, i.e. organic carbon. In this view, the nitrification process is principally governed by the $\mathrm{C} / \mathrm{N}$ ratio as was demonstrated by Woldendorp (1981) and Woldendorp and Laanbroek (1989).

\section{References}

Basaraba J 1964 Influence of vegetable tannins on nitrification in soil. Plant and Soil 21, 8-16.

Belser L W and Mays EL 1982 Use of nitrifier activity measurements to estimate the efficiency of viable nitrifier counts in soils and sediments. Appl. Environ. Microbiol. 43, 945-948.

Berg P and Rosswall T 1985 Ammonium oxidizer numbers, potential and actual oxidation rates in two Swedish arable soils. Biol. Fertil. Soils 1, 131-140.

Blacquière T and Troelstra S R 1992 Nitrogen nutrition in Plantago species. In Plantago: A Multidisciplinary Study. Ecological Studies 89, 105-112. Eds. P J C Kuiper and M Bos. Springer Verlag, Berlin, Germany.

Both G J 1990 The ecology of nitrite-oxidizing bacteria in grassland soils. Ph.D. thesis, University of Groningen, Groningen, The Netherlands.

Clarholm M 1985 Possible roles for roots, bacteria, protozoa and fungi in supplying nitrogen to plants. In Ecological Interactions in the Soil. Special Publication no. 4 of the British Ecological Society. Eds. A H Fitter, D Atkinson, D J Read and M B Usher. pp 355-365. Blackwell, Oxford, England.

Elliot E T, Coleman D C and Cole C V 1979 The influence of amoebae on the uptake of nitrogen by plants in gnotobiotic soil. In The Soil Root Interface. Eds. J L Harley and R S Russel. pp 221-229. Academic Press, London, England.

Freijsen A H J and Otten H 1987 A comparison of the responses of two Plantago species to nitrate availability in culture experiments with exponential nutrient addition. Oecologia (Berlin) $74,389-395$.

Griffiths B S 1989 Enhanced nitrification in the presence of bacteriophagous protozoa. Soil Biol. Biochem. 21, 1045-1051.

Jansson S L 1958 Tracer studies on nitrogen transformations in soil with special attention to mineralization-immobilization relationships. Ann. R. Agric. College Sweden 24, 101-361.

Kuikman P J and van Veen J A 1989 The impact of protozoa on the availability of bacterial nitrogen to plants. Biol. Fertil. Soils 8 , 13-18.

Kuiper P J C and Bos M 1992 Ecophysiology of Plantago species. In Plantago: A Multidisciplinary Study. Ecological Studies 89, 113-183. Springer Verlag, Berlin, Germany.

Laanbroek H J, Smit A J, Klein Nulend G and Veltkamp H 1979 Competition for $\mathrm{L}$ - glutomate between specialized and versatile Clostidium species. Arch. Microbiol. 120, 61-66

McCarty G W, Bremner J M and Schmidt E L 1991 Effects of phenolic acids on ammonia oxidation by terrestrial autotrophic nitrifying organisms. FEMS Microbiol. Ecol. 85, 345-450.

Moore D R E and Waid J S 1971 The influence of washings of living roots on nitrification. Soil Biol. Biochem. 3, 69-83.

Munro P E 1966 Inhibition of nitrifiers by grass root extracts. J. Appl. Ecol. 3, 231-238.

Newman E I and Miller M H 1977 Allelopathy among some British grassland species. J. Ecol. 65, 399-411.

Pirt S J 1975 Predator-prey interactions. In Principles of Microbe and Cell Cultivation. Ed. S J Pirt. pp 205-208. Blackwell, Oxford, England.

Purchase B S 1974 Evaluation of the claim that grass root exudates inhibit nitrification. Plant and Soil 41, 527-539.

Rice E L 1982 Allelopathy. Academic Press, London, England. 353 p.

Rice E L and Pancholy S K 1972 Inhibition of nitrification by climax ecosystems. Am. J. Bot. 59, 1033-1040. 
Richardson H L 1938 Nitrification in grassland soils: with special reference to the Rothamsted Park Grass experiment. J. Agric Sci. 28, 73-121.

Riha S J, Campbell G S and Wolfe J 1986 A model of competition for ammonium among heterotrophs, nitrifiers and roots. Soil Sci. Soc. Am. J. 50, 1463-1466.

Rosswall T 1982 Microbiological regulation of the biogeochemical nitrogen cycle. Plant and Soil 67, 15-34.

Smit A J and Woldendorp J W 1981 Nitrate production in the rhizosphere of Plantago species. Plant and Soil 61, 43-52.

Theron J J 1951 The influence of plants on the mineralization of nitrogen and the maintenance of organic matter in soil. J. Agric. Sci. 41, 289-296.

Theron J J 1963 The mineralization of nitrogen in soils under grass. S. Afr. J. Agric. Sci. 6, 155-164.

Troelstra S R 1992 Chemical and physical characteristics of the soil of Plantago sites. In Plantago: A Multidisciplinary Study. Ecological Studies, Vol. 89. Eds. P J C Kuiper and M Bos. pp 29-48. Springer Verlag, Berlin, Germany.

Verhagen F J M and Laanbroek H J 1991 Competition for ammonium between nitrifying and heterotrophic bacteria in dual energylimited chemostats. Appl. Environ. Microbiol. 57, 3255-3263.

Verhagen F J M and Laanbroek H J 1992 Effects of grazing by flagellates on competition for ammonium between nitrifying and heterotrophic bacteria in chemostats. Appl. Environ. Microbiol. 58, 1962-1969.

Verhagen F J M, Duyts H and Laanbroek H J 1992 Competition for ammonium between nitrifying and heterotrophic bacteria in continuously percolated soil columns. Appl. Environ. Microbiol. 58, 3303-3311.
Verhagen F J M, Duyts H and Laanbroek H J 1993 Effects of grazing by flagellates on competition for ammonium between nitrifying and heterotrophic bacteria in soil columns. Appl. Environ. Microbiol. 59, 2099-2106.

Verhagen F J M, Hageman P E J, Woldendorp J W and Laanbroek $\mathrm{H}$ J 1994a Competition for ammonium between nitrifying bacteria and plant roots in soil in pots; Effects of grazing by flagellates and fertilization. Soil Biol. Biochem. 26, 89-96.

Verhagen F J M, Zölffel M, Brugerolle G and Patterson D J 1994b Adriamonas peritocrescens gen. nov., sp. nov., a new freeliving soil flagellate, (Protista, Pseudodendromonadidae incertae sedis). Eur. J. Protist. 30, 295-308.

Woldendorp J W 1963 The influence of living plants on denitrification. Med. Landbouw Hogeschool Wageningen 63 (13), 1-100.

Woldendorp J W 1981 Nutrients in the rhizosphere. Proc. 16th Coll. Int., Potash Inst., place. pp 99-125.

Woldendorp J W and Laanbroek H J 1989 Activity of nitrifiers in relation to nitrogen nutrition of plants in natural ecosystems. Plant and Soil 115, 217-228.

Zak D R, Groffman P M, Pregitzer K S, Christensen S and Tiedje J M 1990 The vernal dam: plant-microbe competition for nitrogen in northern hardwood forests. Ecol. 71, 651-656.

Section editor: $R$ Merckx 